\title{
Opinions of Turkish Forensic Medicine Specialists about Concept of Death in Turkey
}

H Dokgöz ${ }^{1}$, M Yılmaz², N Türkmen³ ${ }^{3}$ E Özer ${ }^{4}$, MA Sungur ${ }^{5}$, R Y1lmaz ${ }^{6}$

\begin{abstract}
Objectives: This investigation was conducted to determine opinions of forensic medicine specialists about the concept of death.

Methods: This descriptive, cross-sectional and qualitative study was conducted on 103 forensic medicine specialists who consented to participate in the study between 2011-2012. Data were obtained during face-to-face interviews and via email.

Results: Forensic medicine specialists who participated in this study were mostly (74.8\%) male, married (81.6\%) with a mean age of $40.45 \pm 6.85$ years; $24.3 \%$ of them were practising their speciality for $11-$ 15 years. This study revealed that forensic medicine specialists demonstrate a lower level of death anxiety. Conclusions: Forensic medicine specialists demonstrated a moderate level of avoidance attitude, while they manifested a depressive mood towards death.
\end{abstract}

Keywords: Death, death anxiety, depression, forensic medicine, forensic medicine specialist, scale

\section{Opiniones de Especialistas en Medicina Forense Turcos Sobre el Concepto de Muerte en Turquía \\ H Dokgöz ${ }^{1}$, M Yılmaz², N Türkmen³ ${ }^{3}$ E Özer ${ }^{4}$, MA Sungur ${ }^{5}$, R Yılmaz}

\begin{abstract}
RESUMEN
Objetivos: Esta investigación se realizó para determinar la opinión de especialistas en medicina forense sobre el concepto de la muerte.

Métodos: Este estudio descriptivo, transversal, cualitativo se realizó con 103 especialistas en medicina forense que consintieron en participar en el estudio entre 2011-2012. Los datos fueron recolectados en entrevistas cara a cara y vía correo electrónico.

Resultados: Los especialistas en medicina forense que participaron en este estudio fueron en su mayoría hombres (74,8\%), casados (81,6\%) con una edad media de $40.45 \pm 6.85$ años. Un $24.3 \%$ de ellos habian estado practicando su especialidad por espacio de 11 - 15 años. Este estudio reveló que los especialistas en medicina forense demuestran un menor nivel de ansiedad por la muerte.

Conclusiones: Los especialistas en medicina forense demostraron un nivel moderado de actitud de evitación, si bien manifestaron un estado de ánimo depresivo hacia la muerte.
\end{abstract}

Palabras claves: Muerte, ansiedad ante la muerte, depresión, medicina forense, especialista en medicina forense, escala

West Indian Med J 2017; 66 (1): 111

From: ${ }^{1}$ Department of Forensic Medicine, Medical Faculty, ${ }^{2}$ Department of Psychiatric Nursing, High School of health, Mersin University, Mersin, Turkey, ${ }^{3}$ Department of Forensic Medicine, Uludag University, Medical Faculty, Burza, Turkey, ${ }^{4}$ Department of Forensic Medicine, Medical Faculty, Karadeniz Technical University, Trabzon, Turkey, ${ }^{5}$ Department of Biostatics and Bioinformation, Medical Faculty, Mersin University,
Mersin, Turkey and ${ }^{6}$ Department of Forensic Medicine, Medical Faculty, Bulent Ecevit University, Zonguldak, Turkey.

Correspondence: Professor H Dokgöz, Department of Forensic Medicine, Medical Faculty, Mersin University, Mersin, Turkey. Fax: 0090324 2410092, email: halisdokgoz@gmail.com or halisdokgoz@mersin.edu.tr 


\section{INTRODUCTION}

Death is a universal event which is the terminal stage of life shared by all living organisms. Although death is an inevitable truth, its time and mechanism cannot be predicted $(1,2)$. Death has been defined as an irreversible functional loss in the central nervous system, respiratory and cardiovascular systems which are considered as vital organ systems (3). Though death is an inevitable end of life, it can be delayed in parallel with scientific advances in the field of medicine, and life may be prolonged using dialysis therapy and/or respiratory assistive devices. Application of sophisticated tools, and equipments, and palliative treatments also prolong life span of patients (4, 5). However, as an inevitable ultimate truth, death is the most unavoidable bereavement in one's life (6). However, death fear is related to uncertainty. Human beings are afraid of the way of dying rather than death. As is acknowledged, individuals are affected from death event in various ways. Review of relevant investigations has revealed that very different variables were used for the assessment of death anxiety. Among variables related to death anxiety age, gender, marital status, relgious beliefs, developmental process and socio-cultural properties can be enumerated $(7,8)$.

Just like ageing and disease, death is an overlooked and denied phenomenon in many cultures. As is the case with all human beings, health professionals ignore the reality of death. Since healthcare professionals like physicians and nurses are looked upon as members of a life-saving profession, they may experience a feeling of personal failure when confronted with a death and their self-confidence weakens. It has been indicated that healthcare professionals who comprehend and accept death as an integral part of life are more realistic in overcoming challenges of daily life (9-11).

Nowadays, the majority of deaths occur among inpatients which require, healthcare professionals to assume over-whelming responsibilities (1). Mostly death events are discussed and their impact on the feelings of relatives is usually disregarded. It has been emphasized that death events are admittedly destructive in themselves, meditation on death, awareness of this destiny and sharing feelings about death add value to one's personality.

In Turkey, although some investigations have been carried out on healthcare professionals about their attitudes towards death, studies have not been conducted with forensic medicine specialists who perform relevant procedures like death examination and autopsies $(1,6,10,11)$. Acceptance of the reality of death within its natural context will alleviate the traumatic impact of the death event on forensic medicine specialists. Self-awareness of forensic medicine specialists of their feelings, thoughts and attitudes gains priority. Forensic medicine specialists should freely express their feelings and opinions about the concept of death. This approach will contribute favourably to their personal development, protect rights of the patient and increase the quality of healthcare services provided for the relatives of the patient. Besides, it will disclose whether or not forensic medicine specialists need education, and professional healthcare support with respect to their aprroach towards the concept of death.

This study is important with respect to determination of opinions of forensic medicine specialists about the concept of death, provision of more prestigeous, and qualified healthcare services for the dying patients, and their families, and detection of knowledge and skills of forensic medicine specialists.

\section{SUBJECTS AND METHODS}

Design of the Investigation: This descriptive, cross-sectional and qualitative study was conducted in order to determine opinions of forensic medicine specialists about the concept of death.

Place and date of the investigation: This study was conducted on forensic medicine specialists between 01.04.2011 01.04.2012 in affiliated medical units of the Institute of Forensic Medicine, Ministry of Justice and University Hospitals, in Turkey.

The scope of the investigation: The study population consisted of all forensic medicine specialists $(n=300)$ working in the affiliated medical units of the Institute of Forensic Medicine, Ministry of Justice and University Hospitals, in Turkey. Sample size of the investigation: In this study minimal required sampling size was determined as 141 individuals using five and four-point Likert-type scale with \pm 2 standard deviation and 5\% type I margin of error (12). Response rate of $41 \%$ was obtained after analysing questionnaires sent to 100 forensic medicine specialists. Therefore, to reach a minimal range of sampling size, the data collection tools were sent to at least 224 individuals, and only 103 forensic medicine specialists responded to the questionnaire forms.

\section{Preparation of data collection tools}

Data of the investigation were collected using eight-point 'Personal Information Form' and 'Thorson-Powell Death Anxiety Scale', 'Scale of Attitudes towards Death and Dying' and 'Death Depression Scale' developed to determine descriptive data of forensic medicine specialists.

Besides, forensic medicine specialists participating in the study were requested to respond to the questions "According to you, what is the meaning of death?", "What do you feel when you are performing autopsy?" and responses obtained were entered in a computerized software programme. Qualitative content analysis was conducted on these computerized data in consideration of prevalent interpretation of the responses, number of the participants making similar interpretations using the same wording, predicting the meaning between the lines beyond the dictionary definition of the words and specificity of responses $(13,14)$. Each investigator read raw data independently many times to conduct coding studies. Independent studies of the investigators were discussed, and following a consensus reached by all of them, codes were integrated and two themes were obtained. 


\section{Personal information form}

Personal Information Form was designed to determine age, gender, marital status and academic level of the forensic medicine specialists. This form is made of eight-points.

\section{Thorson-Powell death anxiety scale}

Validation and reliability studies of this scale developed by Thorson and Powell (15) and its Cronbach- $\alpha$ value was found to be 0.84 . This is a five-point Likert-type scale consisting of 25 questions. In this scale, anxieties related to death, loss of physical, and mental functions, the next world, loss of bodily integrity, and decomposition after death, dying a painful death are analysed in four dimensions. In all these dimensions, increased scores are interpreted as enhanced death anxiety. Levels of death anxiety are rated as very low (26-50 pts), fair (26-50 pts), moderate (51-75 pts) and high [75-100 pts] (15).

\section{Death depression scale}

Validation, and reliability studies of this scale developed by Templer et al (23) were realized by Yaparel and Yildiz (16), and its Cronbach- $\alpha$ value was found to be 0.84 . The scale consists of 17 items which aim to measure, various aspects of mood as depression, sadness, loneliness, threat, and grief experienced related to death event and code them as "Yes" or "No". Mini-mal and maximal scores of this scale are 0 and 17 points. Absence and presence of depressive mood are indicated with $0-8$ and $8-17$ pts (16).

Scale for the attitude towards death and dying This 23-item, four-point Likert-type scale was developed by Kavas et al (17). The scale consists of four dimensions as 'communication with the dying patient and his/her relatives, 'handing over the caregiving responsibilities', refrain from confronting death event, and the dying patient and 'selfeffi-cacy (self-transcendence)'. Cronbach-alpha value of the scale is 0.75 . The scale score responses as 4, 3, 2 and 1 points, and increase in scores is interpreted as 'avoidance attitude'.

\section{Application of the data collection tools}

Approval of the study was obtained from the Ethics Committee of Mersin University. The aim, and method of the study were explained during face-to-face interviews and/or via e-mail to forensic medicine specialists and their informed consents were obtained. The participants were asked to complete the form by themselves and send them to the investigators via e-mail. Completion of each data collection form took approximately, 20-30 minutes (mean duration, 25 minutes).

\section{Evaluation of the data collection tools}

In the statistical analysis of the data obtained from the study, for categorical data among cross-table statistical analyses, Chisquare or likelihood-ratio test was used. For the calculation of continuous data, and scores of scales in intergroup comparisons, independent samples $t$-test (or Mann-Whitney U test), one-way analysis of variance (ANOVA) or Kruskal-Wallis test were used depending on the distribution of data. To analyse correlations between scales, and scale scores, correlation coefficient was used. For the statistical evaluation of data SPSS 11.5 ve MedCalc ${ }^{\circledR}$ V11.0.1 package software programme was used. The Medical Education Unit, Department of Bioistatistics conducted the statistical calculations.

\section{RESULTS}

Forensic medicine specialists participating in this study were mostly $(74.8 \%)$ male, married $(81.6 \%)$ with a mean age of $40.45 \pm 6.85$ years. Some $(24.3 \%)$ of them were practising their specialty for $11-15$ years and $70.9 \%$ of them had witnessed death of their first-degree relatives and $79.6 \%$ of them did not experience any difficulty while performing autopsies (Table $1)$.

Table 1: Sociodemographic characteristics of forensic medicine specialists $(\mathrm{n}=103)$

\begin{tabular}{llll}
\hline Demographic characteristics & n & \% & \\
\hline Gender & Female & 26 & 25.2 \\
& Male & 77 & 74.8 \\
Marital status & Married & 84 & 81.6 \\
& Single & 19 & 18.4 \\
Professional life (years) & $1-5$ & 18 & 17.5 \\
& $6-10$ & 24 & 23.3 \\
& $11-15$ & 25 & 24.3 \\
& $16-20$ & 13 & 12.6 \\
Witnessed death of a relative & $\geq 21$ & 23 & 22.3 \\
& Yes & 73 & 70.9 \\
I am experiencing difficulties while & No & 30 & 29.1 \\
performing autopsies & Yes & 21 & 20.4 \\
& No & 82 & 79.6 \\
\hline Total & $\mathbf{n}$ & $\mathbf{1 0 3}$ & $\mathbf{1 0 0}$ \\
\hline
\end{tabular}

Theme 1: Death is a New Beginning or an End

For more than half of the participating forensic medicine specialists $(62 \%)$, the meaning of death is the end of a movie or a final curtain in a theater, end of life, end of a biological process or a new beginning. Very few participants (7\%) defined the meaning of death as nothingness.

\section{Theme 2: I am doing what is required from my work and profession}

As a striking finding, nearly half $(42 \%)$ of the forensic medicine specialists who participated in the study stated that they do not feel anything when performing autopsies, instead they are fulfilling the requirements of their profession. They regarded autopsy as the final legal right of the deceased which is a task assumed by them. Very few participants (14\%) have expressed that they had felt deep grief conducting autopsies on children.

Maximal, average and minimal scores which can be obtained fiom the first dimension of (anxiety related to the loss 
of functional, and mental functions) Thorson-Powell Death Anxiety Scale are 32, 16 and 0 points, respectively. While the corresponding scores which can be retrieved from the second dimension (anxieties related to life after death) are 24, 12 and 0 points, respectively. The respective scores which can be gathered from the third dimension (anxieties related to decay and decomposition of the body after death) are 16, 8 and 0 points. Maximal, average and minimal scores which can be obtained from the fourth dimension (anxieties related to dying a painful death) are 28,14 , and 0 points, respectively. Increases in all these subscales are interpreted as enhanced death anxiety and rated as very low (0-25 pts), low (26-50 pts), moderate (51-75 pts), and severe [75-100 pts] (15).

As seen in Table 2, median scores obtained by forensic medicine specialists according to different Thoron-Powell death anxiety subscales were 10.9 pts (1.dimension: anxiety related to the loss of physical and mental functions), 10.4 (2.dimension: anxiety related to the life after death), 4, 5 pts (3.dimension: loss of bodily integrity,/and decomposition of after death) and $13.4 \mathrm{pts}$ (4.dimension: anxiety related to dying a painful death), respectively. According to these results obtained, it can be said that generally forensic medicine specialists have no anxieties related to the loss of physical, and mental functions, life after death, loss of bodily integrity, and decomposition after death, pain and suffering while dying. Forensic medicine specialists had acquired an average total score of 39.3 points as assessed by Thorson-Powell rating scale which demonstrates that forensic medicine specialists had lower levels of death anxiety (Table 2).

Scores calculated as for the first factor (communication with the dying patient, and his/her intimate ones) of the attitude towards death, and the dying were interpreted in three levels (high, 30-40 pts; moderate, 20-30 pts, and low, 10-20 pts) as refraining from getting in contact with the dying patient and his/her intimate relatives (10). Accordingly, median score of 26.2 points retrieved by the forensic medicine specialists in the subscale of communication with the dying patients, and their family demonstrates that they somewhat preferred to avoid getting in contact with these patients and their intimate ones (Table 2).

Scores obtained in the second factor (handing over the caregiving responsibility) of attitude towards death, and the dying scale indicated higher (12-16 pts), moderate (8-12 pts) and mild (4-8 pts) degrees of avoidance from nursing of the dying patient (10). Median score of 11.7 points obtained by the forensic medicine specialists in the handing over of caregiving

Table 2: Distribution of Thorson-Powell death anxiety scale, scale for attitude towards death, and dying and death depression scale scores among study participant forensic medicine specialists $(\mathrm{n}=103)$

\begin{tabular}{|c|c|c|c|c|}
\hline Characteristics & $\begin{array}{l}\text { Participant } \\
\text { (n) }\end{array}$ & Minimum & Maximum & $\begin{array}{l}\text { Mean } \pm \text { SD } \\
\quad x \pm S D\end{array}$ \\
\hline $\begin{array}{l}\text { (TPDAS) (1. Dimension): } \\
\text { (Anxiety related to the Loss of physical } \\
\text { and mental functions) }\end{array}$ & 103 & .00 & 30.00 & $10.9 \pm 7.5$ \\
\hline $\begin{array}{l}\text { (TPDAS) (2. Dimension): } \\
\text { (Anxieties related to the life after death) }\end{array}$ & 103 & .00 & 24.00 & $10.4 \pm 5.7$ \\
\hline $\begin{array}{l}\text { (TPDAS) (3. Dimension): } \\
\text { (Anxieties related to loss of bodily } \\
\text { integrity and decomposition) }\end{array}$ & 103 & .00 & 16.00 & $4.5 \pm 4.1$ \\
\hline $\begin{array}{l}\text { (TPDAS) (4. Dimension): } \\
\text { (Anxieties related to dying a painful death) }\end{array}$ & 103 & 2.00 & 24.00 & $13.4 \pm 4.8$ \\
\hline (TPDAS) (Total score, pts): & 103 & 4.00 & 93.00 & $39.3 \pm 18.4$ \\
\hline $\begin{array}{l}\text { (SATDD) (1. Factor): } \\
\text { (Communication with the dying patient } \\
\text { and his/her intimate ones) }\end{array}$ & 103 & 15.00 & 34.00 & $26.2 \pm 3.5$ \\
\hline $\begin{array}{l}\text { (SATDD) (2. Factor): } \\
\text { (Handing over caregiving responsibility) }\end{array}$ & 103 & 8.00 & 16.00 & $11.7 \pm 2.1$ \\
\hline $\begin{array}{l}\text { (SATDD) (3. Factor): } \\
\text { (Refraining from encountering death and } \\
\text { the dying patient) }\end{array}$ & 103 & 11.00 & 21.00 & $15.7 \pm 2.0$ \\
\hline $\begin{array}{l}\text { (SATDD) (4. Factor): } \\
\text { (Perceived self-efficacy (self-transcendence) }\end{array}$ & 103 & 4.00 & 12.00 & $7.5 \pm 1.5$ \\
\hline (SATDD) (Total score, pts): & 103 & 41.00 & 78.00 & $59.7 \pm 6.4$ \\
\hline Death depression scale (DDSS) & 103 & 2.00 & 15.00 & $7.9 \pm 3.4$ \\
\hline
\end{tabular}

TPDAS: Thorson-Powell death anxiety scale; SATDD: scale for attitude towards death, and dying; DDSS: death depression scale scores 
responsibility subscale have indicated that they demonstrate moderate degrees of avoidance from taking responsibility of providing healthcare services for the the terminally-ill patient.

Scores obtained with respect to the third factor (avoidance of death and the dying) rate attitudes towards avoidance of death, and the dying at 3 levels as high (18-24 pts), moderate (12-18 pts) and low [6-12 pts] (10). Accordingly, as seen in Table 2, average avoidance of death, and the dying scale score obtained by the forensic medicine specialists was 15.7 points which indicated that they had a moderate level of avoidance attitude towards death and the dying.

As for the fourth factor, perceived self-efficacy (selftranscendence) scores rated as high (9-12 pts), moderate (6-9 pts), and low (3-6 pts) levels of self-efficacy. Low levels indicate that physicians felt themselves insufficienct in providing healthcare of the dying patients (10). As analysed in Table 2 , average score of perception of self-efficacy was 7.5 pts, which revealed that forensic medicine specialists had moderate levels of self-efficacy in the caregiving for the dying patients.

Total scores obtained from attitude towards death, and the dying scale were rated as low (23-46 pts), moderate (46-69 pts), and high (69-92 pts) levels of avoidance from dying patients (17). Accordingly, as seen in Table 2, total average score of 59.7 points obtained by forensic medicine specialists in attitude towards death and the dying scale can be attributed to their moderate level of avoidance from dying patients.

Scores obtained from death depression scale are rated as absence ( $0-8$ pts) or presence of depressive mood (16). Within this context, as observed in Table 2, an average of 7.9 points retrieved by forensic medicine specialists in the death depression scale indicates that they did not feel depressed when confronted by a death event.

A positive but a weak correlation existed between Thorson-Powell death anxiety scale, and attitude towards death and the dying $(\mathrm{r}=0.284, p=0.004)$. Based on this result, it can be said that as death anxiety of forensic medicine specialists increased they display an avoidance attitude towards the dying patient (Table 3).
A moderate, and a positive correlation was determined between Thorson-Powell death anxiety, and death depression scale scores of forensic medicine specialists $(\mathrm{r}=0.568$, $p=0.001)$. Based on this result, it can be argued that levels of death anxiety of forensic medicine specialists increase in direct proportion with death depression levels (Table 3).

A positive but a weak correlation was detected between attitude towards death and the dying patient, and death depression scale scores of forensic medicine specialists $(\mathrm{r}=$ $0.389, p=0.001)$. Based on this result, it can be asserted that forensic medicine specialists who demonstrate avoidance behaviour towards the dying patient have also higher death anxiety levels.

A negative, and a weak correlation was determined between ages of forensic medicine specialists participating in the study and the first dimension of Thorson-Powell death anxiety scale which is the anxiety to lose physical, and mental functions $(\mathrm{r}=-0.271, p=0.006)$. According to this result, anxiety levels related to the fear of losing one's physical, and mental functions decrease as they aged (Table 4).

A negative, and a weak correlation was found between the second dimension of Thorson-Powell death anxiety scale (anxiety related to life after death) scores of forensic medicine specialists $(\mathrm{r}=-0.440, p=0.001)$. Considering this result, a decrease in the level of anxiety experienced by forensic medicine specialists about life after death with increasing age can be suggested (Table 4).

A negative and a weak correlation between ages of the forensic medicine specialists, and total Thorson-Powell death anxiety scale scores has been detected $(r=-0.301, p=0.002)$. Regarding this outcome, one can say that death anxiety of forensic medicine specialists decrease as they aged (Table 4).

Distribution of total scores obtained by forensic medicine specialists participating in the study as assessed by Thorson-Powell death anxiety scale, death depression scale, attitude towards death, and the dying scale based on some of the partipants' sociodemographic characteristics are presented

Table 3: Correlations among total scores obtained by forensic medicine specialists as assessed by ThorsonPowell death anxiety scale, attitude towards death and the dying scale and death depression scale

\begin{tabular}{|c|c|c|c|}
\hline & $\begin{array}{l}\text { Thorson-powell } \\
\text { death anxiety } \\
\text { scale total score }\end{array}$ & $\begin{array}{l}\text { Attitude towards } \\
\text { death and the } \\
\text { dying scale total } \\
\text { score }\end{array}$ & $\begin{array}{l}\text { Death depression } \\
\text { scale total score }\end{array}$ \\
\hline \multirow{2}{*}{$\begin{array}{l}\text { Thorson-powell death anxiety scale } \\
\text { total score }\end{array}$} & $\mathrm{r}$ & 0.284 & 0.568 \\
\hline & $\mathrm{p}$ & 0.004 & 0.001 \\
\hline \multirow{2}{*}{$\begin{array}{l}\text { Attitude towards death and the dying } \\
\text { scale total score }\end{array}$} & r $\quad 0.284$ & & 0.389 \\
\hline & p 0.004 & & 0.001 \\
\hline \multirow[t]{2}{*}{ Death depression scale total score } & $\mathrm{r} \quad 0.568$ & 0.389 & \\
\hline & $\mathrm{p} \quad 0.001$ & 0.001 & \\
\hline
\end{tabular}


Table 4: Correlation between ages of forensic medicine specialists and total Thorson-Powell Death anxiety, attitude towards death, and the dying, and death expression scale scores

\begin{tabular}{llr}
\hline & & AGE \\
\hline (TPDAS) (1. Dimension): (Anxiety related to the & $\mathrm{r}$ & -0.271 \\
loss of physical and mental functions) & $\mathrm{p}$ & 0.006 \\
(TPDAS) (2. Dimension): (Anxiety related to & $\mathrm{r}$ & -0.440 \\
life after death) & $\mathrm{p}$ & 0.001 \\
(TPDAS) (3. Dimension): (Anxiety related to the & $\mathrm{r}$ & -0.092 \\
loss of bodily integrity and decomposition after death) & $\mathrm{p}$ & 0.358 \\
& & \\
(TPDAS) (4.Dimension):(anxieties related to & $\mathrm{r}$ & -0.122 \\
dying painful death) & $\mathrm{p}$ & 0.220 \\
& $\mathrm{r}$ & -0.301 \\
(TPDAS) (Total score): & $\mathrm{p}$ & 0.002 \\
& $\mathrm{r}$ & -0.037 \\
(SATDD) (1. Dimension): (Communication with & $\mathrm{p}$ & 0.714 \\
the dying patient and his/her intimate ones) & & \\
& $\mathrm{r}$ & -0.142 \\
(SATDD) (2. Dimension): (handing over & $\mathrm{p}$ & 0.152 \\
caregiving responsibility) & $\mathrm{r}$ & -0.110 \\
& $\mathrm{p}$ & 0.269 \\
(SATDD) (3. Dimension): (Avoidance of death & $\mathrm{r}$ & 0.093 \\
and the dying) & $\mathrm{p}$ & 0.351 \\
& $\mathrm{p}$ & -0.076 \\
(SATDD) (4. Dimension): (Perception of & $\mathrm{p}$ & 0.443 \\
self-efficacy) & $\mathrm{r}$ & -0.144 \\
(SATDD) (Total score): & 0.147 \\
\hline &
\end{tabular}

in (Table 5). Statistically significant difference could not be detected between some sociodemographic characteristics of forensic medicine specialists and distribution of total scores recorded in Thorson-Powell death anxiety scale, death depression scale, attitude towards death and the dying scale survey forms (Table 5).

A statistically significant difference was found between the duration of professional life of participating forensic medicine specialists and average Thorson-Powell death anxiety scale scores $(p<0.004)$. According to this outcome forensic medicine specialists with a professional life of 11-15 years demonstrated higher levels of death anxiety when compared with those with professional life of $\geq 21$ years.

\section{DISCUSSION}

A number of studies have approached death anxiety as an unidimensional construct. Most, however, have taken the approach that a number of different factors or elements make-up the personal fear of death. Detailing the great number of different approaches to measuring these various elements of death anxiety goes beyond the scope of these papers (18).

Forensic medicine specialists participating in this study were mostly $(74.8 \%)$ male, married $(81.6 \%)$ with a mean age of $40.45 \pm 6.85$ years. Approximately $24.3 \%$ of them were practising their specialty for $11-15$ years and $70.9 \%$ of them had witnessed death of their first-degree relatives and $79.6 \%$ of them did not experience any difficulty while performing autopsies (Table 1). These results reveal that forensic medicine specialists who confront cases of trauma, autopsies, and death

Table 5: Mean Thorson-Powell death anxiety scale, attitude towards death, and the dying, and death depression scale scores categorized according to sociodemographic characteristics of forensic medicine specialists $(n=103)$

\begin{tabular}{|c|c|c|c|c|c|c|c|c|c|c|}
\hline \multirow[t]{2}{*}{$\begin{array}{c}\text { Socio- } \\
\text { demographic } \\
\text { characteristics }\end{array}$} & & \multicolumn{3}{|c|}{$\begin{array}{l}\text { Attitude towards } \\
\text { death and the } \\
\text { dying scale } \\
\text { Total score }\end{array}$} & \multicolumn{3}{|c|}{$\begin{array}{c}\text { Death } \\
\text { depression } \\
\text { Scale } \\
\text { Total score }\end{array}$} & \multicolumn{3}{|c|}{$\begin{array}{c}\text { Thorson-Powell } \\
\text { Death Anxiety } \\
\text { Scale } \\
\text { Total score }\end{array}$} \\
\hline & & $\lambda$ & SS & $p$ & $\lambda$ & SS & $p$ & $\lambda$ & SS & $p$ \\
\hline Gender & $\begin{array}{l}\text { Female } \\
\text { Male }\end{array}$ & $\begin{array}{l}60.42 \\
59.55\end{array}$ & $\begin{array}{l}7.89 \\
5.90\end{array}$ & 0.556 & $\begin{array}{l}8.15 \\
7.85\end{array}$ & $\begin{array}{l}3.36 \\
3.50\end{array}$ & 0.707 & $\begin{array}{l}35.53 \\
40.64\end{array}$ & $\begin{array}{l}20.05 \\
17.76\end{array}$ & 0.201 \\
\hline Marital status & $\begin{array}{l}\text { Married } \\
\text { Single }\end{array}$ & $\begin{array}{l}59.83 \\
59.52\end{array}$ & $\begin{array}{l}6.02 \\
8.17\end{array}$ & 0.852 & $\begin{array}{l}7.76 \\
8.68\end{array}$ & $\begin{array}{l}3.45 \\
3.46\end{array}$ & 0.296 & $\begin{array}{l}39.70 \\
37.84\end{array}$ & $\begin{array}{l}18.50 \\
18.39\end{array}$ & 0.693 \\
\hline $\begin{array}{l}\text { Witnessed } \\
\text { bereavement of } \\
\text { a relative }\end{array}$ & $\begin{array}{l}\text { Yes } \\
\text { No }\end{array}$ & $\begin{array}{l}59.84 \\
59.60\end{array}$ & $\begin{array}{l}6.44 \\
6.52\end{array}$ & 0.859 & $\begin{array}{l}8.06 \\
7.60\end{array}$ & $\begin{array}{l}3.44 \\
3.52\end{array}$ & 0.535 & $\begin{array}{l}39.53 \\
38.93\end{array}$ & $\begin{array}{l}17.55 \\
20.64\end{array}$ & 0.881 \\
\hline $\begin{array}{l}\text { Experienced } \\
\text { difficulties in } \\
\text { performing } \\
\text { autopsies }\end{array}$ & $\begin{array}{l}\text { Yes } \\
\text { No }\end{array}$ & $\begin{array}{l}60.52 \\
59.58\end{array}$ & $\begin{array}{l}6.69 \\
6.39\end{array}$ & 0.553 & $\begin{array}{l}8.95 \\
7.67\end{array}$ & $\begin{array}{l}4.04 \\
3.26\end{array}$ & 0.130 & $\begin{array}{l}44.90 \\
37.93\end{array}$ & $\begin{array}{l}21.64 \\
17.34\end{array}$ & 0.122 \\
\hline $\begin{array}{l}\text { Duration of } \\
\text { professional } \\
\text { life (years) }\end{array}$ & $\begin{array}{l}1-5 \\
6-10 \\
11-15\end{array}$ & $\begin{array}{l}61.11 \\
60.58 \\
59.32\end{array}$ & $\begin{array}{l}5.59 \\
8.73 \\
6.06\end{array}$ & 0.473 & $\begin{array}{l}8.61 \\
7.87 \\
8.96\end{array}$ & $\begin{array}{l}3.27 \\
3.72 \\
4.14\end{array}$ & 0.195 & $\begin{array}{l}44.22 \\
43.50 \\
45.48\end{array}$ & $\begin{array}{l}21.40 \\
19.10 \\
18.06\end{array}$ & 0.004 \\
\hline & $16-20$ & 57.07 & 6.82 & & 6.76 & 1.64 & & 31.23 & 15.60 & \\
\hline & $\geq 21$ & 59.91 & 3.96 & & 7.00 & 3.03 & & 29.17 & 10.86 & \\
\hline
\end{tabular}


are relatively experienced when we consider their ages, and duration of their practice in the field of forensic medicine which is important in the evaluation of their attitudes towards the concept of death.

Forensic medicine specialists participating in the study were requested to respond to the questions 'According to you, what is the meaning of death?', 'What do you feel when you are performing an autopsy?' and consequently two themes were obtained. First. theme; 'Death is a new beginning or end'. For more than half of the participating forensic medicine specialists $(62 \%)$ the meaning of death as the end of a movie or a final curtain in a theater, end of life, end of a biological process or a new beginning. Very few participants (7\%) defined the meaning of death as nothingness. The second. theme has been expressed as 'I am doing what is required from my work and profession'.

As a striking finding, nearly half $(42 \%)$ of the forensic medicine specialists who participated in the study stated that they did not feel anything when performing autopsies, instead they were fulfilling the requirements of their profession. They regarded autopsy as the final legal right of the deceased which is a task assumed by them. Very few participants (14\%) expressed that they had felt deep grief while conducting autopsies on children.

It can be suggested that forensic medicine specialists participating in the study had not entertained an anxious attitude towards loss of their physical, and mental functions, life after death, postmortem loss of bodily integrity, and decomposition, and suffering from pain and agony while dying. Forensic medicine specialists had gathered a total average score of 39.7 points as assessed by Thorson-Powell death anxiety scale which indicates that they had a lower level of death anxiety (Table 1). In some studies, training programmes aiming to decrease death anxiety were successful in alleviating it significantly $(19,20)$. However, a separate metaanalysis indicated that this type of training courses had not decreased, but even increased death anxiety. This discrepancy has been attributed to the differences between educational programmes about concept of death, sampling sizes, and tools of assessment (21). We think that forensic medicine specialists who personally encounter death events and perform autopsies should be trained about death anxiety.

Moderate degrees of avoidance behaviour were demonstrated by forensic medicine specialists with respect to communication with the dying patients, their intimate ones, death and the dying. Still, regarding caregiving responsibility, and perception of self-efficacy in patient's healthcare, forensic medicine specialists demonstrated moderate degrees of avoidance behaviour (Table 2). The level of death anxiety is higher in female physicians than male physicians, and lower levels were detected in physicians who encountered dying patients more frequently (22). A study performed by Templer et al revealed that death anxiety was more severely felt by women. The issue, whether or not frequent encounters with fatal diseases decrease or increase death anxiety or individuals who fear greatly the concept of death prefer to practice in disciplines where they cannot possibly encounter dying patients, has not been clarified yet. However, according to this study, when compared with those working in the field of basic medical sciences, specialists practising in various disciplines, and subspecialities of surgery are mostly male physicians who encounter dying patients more frequently which lower their levels of death anxiety. The statements as 'All good, and bad news about the diagnosis, and treatment of the patient with established fatal disease had to be told to the patient', and 'Even though terminally-ill patients are incognizant of their diagnosis, they are aware of their dire destiny' are more favoured by specialists in basic medical sciences rather than physicians practicing in various fields of surgery (23). Similarly, in our study forensic medicine specialists who frequently encountered death events had experienced moderate degrees of death anxiety.

The average score of 7.9 points obtained by forensic medicine specialists, as evaluated using the death depression scale indicated that they did not feel depressed when confronting a death event (Table 2). A positive and a moderate degree of correlation was determined between ThorsonPowell death anxiety, and death depression scale scores $[\mathrm{r}=$ 0.568, $p=0.001$ ] (Table 3). Accordingly, death depression levels of the forensic medicine specialists can increase in line with the level of their death anxieties. Similarly, in a recent study, higher death anxiety mean scores had been detected in patients with higher depression scores (24). Presence of a correlation between depression and death anxiety might be thought to confirm the association between emotional states and death anxiety.

It can be suggested that forensic medicine specialists participating in the study had demonstrated a positive, but a weak correlation between their Thorson-Powell death anxiety, and attitude towards death, and the dying scale scores $[\mathrm{r}=0.284$, $p=0.004$ ] (Table 3) and they displayed an avoidance behaviour towards dying patients. When death anxiety levels were compared, relative to physicians with lower levels of death anxiety, those with higher levels of anxiety more frequently stated that they had experienced difficulties during their contact with dying patients, and their families and experienced emotional dilemmas when giving news about a fatal disease or death event. However, they were less prone to consent to the statement, 'disclosure of a diagnosis of a fatal disease do not influence the prognosis, and emotional state of the patient' (22). It should be considered that because of adverse impact of directly encountering a dying patients, and a death event, the physician might be reflecting their own death anxieties.

A positive but a weak correlation was detected between attitude of forensic medicine specialists towards death, and the dying, and their death depression scale scores $[\mathrm{r}=0.389$, $p=0.001]$ (Table 3). It can be said that death depression scale scores increase among forensic medicine specialists who ma- 
nifest avoidance behaviour towards dying patients. It has been determined that those perceiving death as a phenomenon of annihilation experienced death anxiety more deeply, while those who interpreted death and the concept of death more favourably had lower death anxiety scores $(25,26)$.

A negative and weak correlation was revealed between the ages of forensic medicine specialists, and the anxiety to lose their physical, and mental functions which is the first dimension of Thorson-Powell death anxiety scale $(\mathrm{r}=-0.271$, and $p=0.006$ ). Accordingly, as the specialist aged in the profession, the impact of this anxiety weakens gradually. It has been also stated that the anxiety felt by forensic medicine specialists about death, and life after death had alleviated gradually with ageing. In a study performed by Ayten et al (27) it was reported that in old age, death which is perceived as 'nearing reality' caused less anxiety when compared with other stages of life ie youth (27).

A statistically insignificant difference between some sociodemographic characteristics of forensic medicine specialists, and distribution of total scores of Thorson-Powell death anxiety scale, death depression scale, and attitude towards death and dying was detected (Table 5). A statistical significant difference was found between duration of professional life of forensic medicine specialist participants and mean scores of Thorson-Powell death anxiety scale scores $(p<$ 0.004). Accordingly, forensic medicine specialists with a professional life of 11-15 years had obtained higher death anxiety scores than those specialists working in the same field for $\geq$ 21 years which shows that anxiety can be overcomed as years and experience in the profession accumulate.

\section{REFERENCES}

1. Koç Z, Sağlam Z. Determining the emotions and opinions of nursing students related to end-of-life care and death state. J Cumhuriyet Univ Sch Nurs 2008; 12: 1-10. (In Turkish)

2. Oz F. Uncertainty in illness experience. Turkish J Psych 2001; 12: 61-8. (In Turkish)

3. DiMaio VJ, DiMaio D. Medicolegal Investigative Systems. In: Forensic Pathology. CRC Pres LLC, Sec Ed 2001; 1-24.

4. Patrick LD, Curtis RJ, Engelberg AR, Nielsen E, McCown E. Measuring and improving the quality of dying and death. Ann Intern Med 2003; 139: $410-15$.

5. Zerzan J, Steans S, Hanson L. Access to palliative care and hospice in nursing homes. Jama 2000; 284: 2489-94.

6. Okyayüz U. Death and fatal disease. J Crisis 1995; 3: 185-89. (In Turkish).
7. Fortner BV, Neimeyer RA. Death anxiety in older adults: a quantitative review. Death Stud 1999; 5: 387-411.

8. Smith GA. Exploring death anxiety with older adults through developmental transformations. The Arts in Psychotherapy, 2000; 5: 321-31.

9. Viswanathan R. Death anxiety, locus of control, and purpose in life of physicians: their relationship to patient death notification. Psychosomatics 1996; 4: 339-45.

10. Özaltın G, Işı1 Ö. An ınvestıgatıon of nursıng students approaches to death. Turkiye Klinikleri J Med Ethics 1997; 1: 10-15. (In Tukish)

11. İnci $\mathrm{F}$. Effects of death education on anxiety, depression, and attitudes of nurses. Phd Thesis, Hacettepe University Institute of Health Sciences, Ankara, 2008. (In Tukish)

12. Bartlett JE, Kotrlik JW, Higgins CC. Organizational research: determining appropriate sample size in survey research. Information Technology, Learning and Performance Journal 2001;19: 43-50.

13. Streubert HJ, Carpenter DR. Qualitative research in nursing advancing the humanistic imperative. $2^{\text {nd }}$ ed, Lippincott, Philadelphia 1999; New York, Baltimore.

14. Kümbetoğlu B. Qualitative methods and research in sociology and anthropology, Bağlam Press, İstanbul 2005; 30-45. (In Tukish)

15. Karaca F, Yıldiz M. Thorson-powell death anxiety scale Turkish validity and reliability study of the normal population. Tabula-Rasa 2001; 1: 43-55. (In Tukish)

16. Yaparel R, Yıldız M. A study on the reliability and validity of the Turkish version of death depression scale in the normal population. Turkish $\mathrm{J}$ Psych 1998; 3:198-200. (In Tukish)

17. Kavas MV. The efficacy of narrative methods in the ethical education on "approach to death and dying patient". Phd Thesis, Ankara University Institute of Health Sciences, Ankara, 2008. (In Tukish)

18. Thorson JA, Powell FC. A revised death anxiety scale, Death Stud 1992; 6: $507-21$.

19. Thompson LE. Attitudes toward death and dying: an educational intervention for reduction of death anxiety. The Degree Doctor of Education, The University of South Dakota, 1983.

20. Lally MT. Death anxiety and fear of death attitudes: a death education program for student nurses. The Degree Doctor of Philosophy, Loyola University, 1983.

21. Maglio CJ, Robinson SE. The effects of death education on death anxiety: A meta-analysis: Omega: Journal of Death and Dying 1994; 4: 319-35.

22. Özkıriş A, Güleç G, Yenilmez Ç, Musmul A, Yanaş M. A study on the attitudes of physicians: approach towards death and terminally ill. Düşünen Adam J Psych Neurol Sci 2011; 24: 89-100. (In Tukish)

23. Templer DI. The construction and validation of death anxiety scale. J Gen Psychol 1970; 82: 165-77.

24. Öztürk ZK. Death anxiety in elderly cases. Thesis, Çukurova University Faculty of Medicine Department of Psychiatry, Adana 2010. (In Tukish)

25. Knight KH, Elfenbein MH. Relationship of death education to anxiety, fear, and meaning associated with death. Death Stud 1993; 17: 411-25.

26. Cicirelli VG. Personal meanings of death in relation to fear of death. Death Stud 1998; 8: 713-33.

27. Ayten A. Death anxiety among university students: a comparison study on turkish and jordanian students. JAcademic Research in Religious Sci, 2009; 4: 85-108. (In Tukish) 